\title{
EFFECTS OF ADDING NANO-CHITOSAN ON PRODUCTIVE PERFORMANCE OF LAYING HENS
}

\author{
G. A. A. Hamady ${ }^{1}$ and K. Y. Farroh ${ }^{\Upsilon}$ \\ ${ }^{1}$ Animal Production Department, Faculty of Agriculture, Al-Azhar University, Nasr City, Cairo, Egypt. \\ ${ }^{2}$ Nanotechnology and Advanced Materials Central Lab, Agricultural Research Centre, Giza, Egypt.
}

(Received 28/1/2020, accepted 3/3/2020)

\section{SUMMARY}

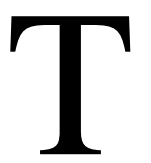

he present study evaluated the effects different forms of chitosan (ordinary chitosan "OCh" and chitosan nanoparticles "ChNP") as a dietary supplementation on egg production, egg quality, yolk egg composition, blood serum traits, and intestinal bacteria. A total of 96 hens of Bábolna TETRA-SL at 23 weeks of age were randomly assigned into 4 experimental groups with three replicates each. The control (Co) group, T1 group, and T2 group were fed $0.0 \mathrm{mg} / \mathrm{kg}$ diet, $150 \mathrm{mg} / \mathrm{kg}$ diet and $300 \mathrm{mg} / \mathrm{kg}$ diet, respectively. The control group (Co) were fed the basal diet without the supplement, while birds in the treatment groups $\mathrm{T}_{1}, \mathrm{~T}_{2}$, and $\mathrm{T}_{3}$ were fed the basal diet supplemented with $200 \mathrm{mg} \mathrm{OCh} / \mathrm{kg}$ diet, $50 \mathrm{mg} \mathrm{ChNP} / \mathrm{kg}$ diet, and $200 \mathrm{mg} \mathrm{ChNP} / \mathrm{kg}$ diet, respectively. The experimental period was 12 weeks (23-34 weeks old). The egg laying rate, average egg weight, and feed conversion ratio of hens were not affected significantly by the experimental groups. Egg mass and feed intake were significantly decreased $(\mathrm{P}<0.05)$ for all treatments compared to the control group. Albumen height and Haugh unit were significantly increased in the $\mathrm{T} 1$ and $\mathrm{T} 3$ groups compared to the control group $(\mathrm{P}<0.05)$. Unsaturated fatty acids ( $\Sigma$ USFA) were significantly increased in the T1 and T3 compared to the other groups $(\mathrm{P}<0.05)$. However, saturated fatty acids ( $\mathrm{SFA})$ were significantly decreased in the T1 and T3 groups compared to the other groups $(\mathrm{P}<0.05)$. Malondialdehyde concentration was significantly decreased in the T1 and T3 groups $(\mathrm{P}<0.05)$ compared to the Co group. Immunoglobulin $\mathrm{Y}$ was significantly increased $(\mathrm{P}<0.05)$ in the $\mathrm{T} 1$ group followed by decreasing order in the $\mathrm{T} 3$ group. Total bacterial count, including Lactobacillus count in the intestine was significantly increased $(\mathrm{P}<0.05)$ in the T1 and T3 groups compared to the other groups. These results concluded that both of OCh and ChNP have a positive effect on the productive performance of laying hens.

Keywords Chitosan, nanoparticles, egg production, egg quality, intestinal bacteria and laying hens. 


\section{Hamady and Farroh}

\section{INTRODUCTION}

As the global population grows, the need for egg production increases as the cheapest source of high-quality animal protein. In poultry, bacterial infections are responsible for economic loss and low poultry production because of the decreased feed intake, egg rate, digestive integrity, mortality, and medication costs. Therefore, international attention has turned to the search for feed additives from natural and safe sources as an alternative to antibiotics, which caused potential adverse effects, such as antibiotic residues, environmental pollution, and emergence of antibiotic-resistant bacteria. Therefore, since March 2006, the European Union (EU) has banned the use of antibiotics as catalysts for growth in animal production (European Union, 2003). In past years, a wide range of functional materials has been used as a substitute for antibiotics to prevent disease and promote growth in poultry production. These substrates include prebiotics, probiotics, plant extracts and other bioactive compounds (Zhou et al., 2012 and Attia et al., 2018). Chitosan is a deacetylated form of chitin, which is extracted from the exoskeletons of invertebrates, such as crabs, shrimps, insects, and squid (Nwe et al., 2009, Singla and Chawla, 2001 and Tømmeraas et al., 2011). After the chitosan was shown to be reliable and safe, it was approved by the U.S. Food and Drug Administration (FDA) in 2001 (Kong et al., 2010 and Wang et al., 2020) Chitosan (Ch) is one of the promising natural polymers that can be developed to polymeric nanoparticles (NPs), and chitosan has attracted great attention due to its attractive properties (Naskar $e t$ al., 2019). Chitosan can be used in a wide range of applications, including agriculture, food science, pharmaceuticals, and biomedical fields, due to its unique biological characteristics, including biodegradability, and non-toxicity (Naskar et al., 2019 and Yin et al., 2009). Some studies showed that feeding a diet containing 1.4 grams of chitosan / $\mathrm{kg}$ of body weight daily to laying hens, led to hypolipidemic and reduced cholesterol, triglycerol and free fatty acids in serum (Hirano et al., 1990).

Abdominal fat was significantly reduced after chitosan supplementation at a level of $0.025 \%$ and $0.05 \%$ in broilers (Sirsat Shraddha et al., 2017). However, Egg weight and egg component weights were not affected by chitosan supplementation at a level of 20 or $30 \mathrm{~g}$ chitosan/ $\mathrm{kg}$ diet during 29-37 weeks of age (Nogueira et al., 2003). Palmitic and stearic acids contents in eggs were lower in the groups supplemented with 20 or $30 \mathrm{~g}$ than in the control group, while oleic acid in eggs in the group supplemented with $30 \mathrm{~g}$ was higher than in the control group at 37 weeks of age. Egg yolk cholesterol was reduced by a diet containing $30 \mathrm{~g} / \mathrm{kg}$ chitosan at $35-37$ weeks of age compared to the control group. Yan et al., (2010) indicated that egg weight, yolk color and Haugh units were linearly improved in a diet containing $0.01 \%$ or $0.02 \%$ of chitosan, while the egg production was not affected. In another study by Swiatkiewicz et al., (2013) birds that fed a diet containing a high level of distillers dried grains with soluble (DDGS) $(20 \%)$ or chitosan $(0.01 \%)$ had a large number of eggs with an increased egg mass. The incorporation of chitosan a level of $0.02 \%$ or $0.04 \%$ in the diet of laying hens showed a positive effect on laying egg rate, egg quality, Haugh Units, and apparent digestibility of dry matter and nitrogen (Meng et al., 2010). In recent years, a lot of attention has been paid to the use of biodegradable polymeric nanoparticles in poultry nutrition to promote production. There are very limited published studies worldwide on the use of a diet supplemented with chitosan nanoparticles (ChNP) for laying hens. Despite the unique biological properties of $\mathrm{Ch}$, so far little is known about whether ChNP supplement provides measurable health benefits. Therefore, the objective of this study was to evaluate the effects of adding ChNP with a size up to $17 \mathrm{~nm}$ to the diet of laying hens during 23-34 weeks of age on egg production, egg quality, yolk egg composition, blood serum traits, and intestinal bacteria. 


\section{MATERIALS AND METHODS}

\section{Preparation of chitosan nanoparticles:}

Chitosan nanoparticles (ChNP) were prepared by an ionic gelation method according to Calvo et al. (1997) with some modifications. The method utilizes the electrostatic interaction between the amine group of chitosan (Sigma-Aldrich, USA, molecular weight 50,000-190,000 Da, degree of deacetylation 75-85\% and viscosity: 20-300 cP) and a negatively charged group such as sodium tripolyphosphate (TPP) (Sigma-Aldrich, USA). DNA free deionized water (Millipore, USA) was used for preparation and dilutions. Ch aqueous solution $(0.2 \% \mathrm{w} / \mathrm{v})$ was prepared by dissolving $\mathrm{Ch}$ in acetic acid solution ( $1 \% \mathrm{v} / \mathrm{v})$ at room temperature. Subsequently, TPP solution $(0.06 \% \mathrm{w} / \mathrm{v})$ was added dropwise to $\mathrm{Ch}$ solution under vigorous stirring for $30 \mathrm{~min}$. The resulting chitosan particle suspension was centrifuged at $12000 \mathrm{~g}$ for $30 \mathrm{~min}$. The pellet was resuspended in deionized water. The chitosan nanoparticles suspension was then freeze-dried before further use or analysis.

\section{Characterization of chitosan nanoparticles:}

Actual morphology of the prepared Ch nanoparticles was imaged by High Resolution Transmission Electron Microscope (HR-TEM) operating at an accelerating voltage of $200 \mathrm{kV}$ (Tecnai G2, FEI, Netherlands). Diluted Ch nanoparticle solution was ultra-sonicated for $5 \mathrm{~min}$ to reduce the particles aggregation. Using micropipette, three drops from the sonicated solution were deposited on carbon coated-copper grid and left to dry at room temperature.HR-TEM images of the $\mathrm{Ch}$ nanoparticle that deposited on the grid were captures for morphological evaluation. Dynamic Light Scattering (DLS) technique was utilized to estimate the average particle size distribution that was measured by zeta sizer (Malvern, ZS Nano, UK). The chemical structure of the prepared Ch nanoparticles was assessed using X- ray Diffraction (XRD) technique. The corresponding XRD pattern was recorded in the scanning mode (X'pert PRO, PAN analytical, Netherlands) operated by $\mathrm{Cu} \mathrm{K}$ radiation tube $=\left(1.54 \mathrm{~A}^{\circ}\right)$ at $40 \mathrm{kV}$ and $30 \mathrm{~mA}$. The obtained diffraction pattern was interpreted by the standard ICCD library installed in PDF4 software. All the preparation and characterization processes were conducted at Nanotechnology and Advanced Materials Central Lab (NAMCL), Agricultural Research Center, Egypt.

\section{Diet and management:}

A total number of 96 hens of Bábolna TETRA-SL at 23 weeks of age were randomly divided into 4 experimental groups with three replicates. The experimental period was 12 weeks (23-34 weeks old). The control group Co, $\mathrm{T}_{1}, \mathrm{~T}_{2}$ and $\mathrm{T}_{3}$ were fed without addition, $200 \mathrm{mg}$ ordinary chitosan $/ \mathrm{kg}$ diet, $50 \mathrm{mg} \mathrm{ChNP} / \mathrm{kg}$ diet, and $200 \mathrm{mg} \mathrm{ChNP} / \mathrm{kg}$ diet, respectively. Laying hens were housed in pyramid shaped batteries, which were equipped with water and feeders (dimensions: $45 \mathrm{~cm}$ in length, $45 \mathrm{~cm}$ in width, and $45 \mathrm{~cm}$ in height). Daily temperature and relative humidity were approximately $22 \pm 2.0 \mathrm{C}^{\circ}$ and $40 \pm 3.0 \%$ during the experimental period. The batteries were cleaned, vaporized with formaldehyde solution, and washed before the start of the experiment. The lighting program used was $16 \mathrm{~L}: 8 \mathrm{D}(\mathrm{L}=$ light, $\mathrm{D}=$ darkness), with an automatic ventilation during the whole experimental period. The conditions of housing and management of birds were similar during the experimental period. The mean weight at the start of the experiment for hens was $1745 \pm 41 \mathrm{~g}$. All diets were formulated to provide the nutrient requirements according to Tetra-SL LL guide (2018). The chemical diet composition of the experimental diets (Table, 1) according to (NRC, 1994). Water and feeds were offered ad libitum for hens during the experimental period. Determination of crude protein and ether extract for treatments were carried out in the diet according to AOAC (2012). 


\section{Fatty acids, cholesterol content and lipid oxidation of egg yolk:}

Six eggs from each group were randomly collected at the end of experimental period (34 weeks of age) to determine their fatty acid (FA) content of yolk in eggs produced by laying hens. The yolks were, separated from albumen and quickly frozen at $-20^{\circ} \mathrm{C}$. Total lipids from eggs yolk were extracted by the method of Folch et al. (1957). Methyl esters of fatty acid (FA) were prepared to determine the contents of FA as described by Pearson's Chemical Analysis of Food Eighth Edition (1981). Gas chromatography, the HP (Hewlett Packard) 6890 GC model with mass spectrometer (GC/MS) was used to analyze fatty acids in samples. Yolk lipid oxidation was estimated using 6 eggs, which were randomly collected from each group to determine malondialdehyde (MDA) content described by Racanicci et al. (2008). Six eggs were randomly collected from each replicate at 34 weeks old. All yolks were cleaned from the albumen, mixed well, and freeze-dried. After freeze-drying, they were weighed, homogenized, vacuum packed in plastic bags, and stored at $-20{ }^{\circ} \mathrm{C}$ prior to analysis. Yolk cholesterol concentrations were measured by an enzymatic colorimetric test described by Mannheim, (1989).

\section{Egg quality traits:}

At the end of the experimental period, eight fresh eggs from each replicate were randomly selected at $10 \mathrm{am}$ to measure the egg quality traits, including egg weight, yolk weight, shell weight, albumen weight, yolk color, shell thickness (mm), albumen height $(\mathrm{mm})$ and Haugh Unit. The individual weight of eggs was recorded, and then each egg was broken Egg yolk and albumen were carefully separated. Further separation of the chalaza from the yolk was made by carefully rolling the yolk several times on a moistened paper towel. Yolk weight and shell weight of each egg were then recorded. Shell weight included shell membrane was air-dried for $24 \mathrm{~h}$ and then was recorded. Albumen weight was calculated by subtracting yolk and shell weight from egg weight. For measurement of albumen high, the egg was broken on a smooth level surface, and the albumen height was determined away from the chalaza. Albumen height was measured using a tripod micrometer. Shell thickness with shell membrane was measured by using an Ames shell thickness gauge reading to the nearest $0.01 \mathrm{~mm}$. The DSM Roche Yolk Color Fan was used to measure the color of the egg yolk. Haugh unit was measured according to the method of Haugh, (1937) by the following formula: Haugh Unit $=100 \log \left(\mathrm{H}-1.7 \mathrm{~W}^{0.37}+7.6\right)$. Where: $\mathrm{H}=$ Albumen height and W= Egg weight.

\section{Blood parameters:}

Blood samples were collected from 6 hens, which were randomly selected from each group at end of the experiment. Blood was taken from the jugular vein. Then the serum was isolated from samples by centrifugation at $3000 \mathrm{rpm}$ for $15 \mathrm{~min}$ and saved at $-20{ }^{\circ} \mathrm{C}$ for future uses. The serum total protein was determined according to the methods described by Henry et al. (1974). The total cholesterol, high-density lipoprotein, and low-density lipoprotein were determined by calorimetric methods according to (Richmond, 1973), high-density lipoprotein (Lopez et al. 1977), and low- density lipoprotein (Wieland and Seidel 1983), respectively. Serum immunoglobulins, including IgA, IgY, and IgM were determined as follows: One $\mathrm{ml}$ of $4 \%$ sheep red blood cells (SRBCs) was injected into 6 hens from each group through the left-wing vein at 33 wks of age. Seven days after the injection (at 34 wks), blood samples were taken from the hens through the jugular vein. Serum immunoglobulin (IgA, IgY and IgM) concentrations were determined by ELISA (Microplate Reader ${ }^{\circledR}$ - DAS) using a commercial kit as explained by Hogenesch et al. (2002). 


\section{Hamady and Farroh}

\section{Microbial populations:}

Six intestinal samples were collected from each treatment. The contents of the intestine were removed and placed in a sterile sample bag and put in a cooler box with ice packs $\left(-4\right.$ to $\left.-10{ }^{\circ} \mathrm{C}\right)$ and immediately transported to the laboratory to be tested bacteriologically within a time limit. Lactobacillus, coliform, Enterococcus, Salmonella, and Clostridia counts were determined. Content of samples were then diluted serially from $10^{-1}$ to $10^{-7}$. One-tenth milliliter of each diluted sample was immersed on the appropriate agar media. Bacterial counts were performed using the appropriate dilution and plate culture techniques under aerobic or anaerobic conditions according to Quinn et al. (1994) and Rada et al. (1999).

\section{Statistical analysis:}

Data analysis was performed using SPSS software program package (SPSS, 2001). All data were analyzed based on a completely randomized design using one-way ANOVA and Duncan's multiple range test. Data were presented as means (Means \pm SEM) (Duncan, 1955). All statements of statistical significance are based on a probability of $(\mathrm{P}<0.05)$.

\section{RESUILTS AND DISCUSSION}

\section{Characterization of chitosan nanoparticles:}

Physicochemical characterization of the synthesized ChNPs to evaluate its properties using different techniques is shown in Figure (1). HR-TEM electrograph showed nearly spherical shape, smooth surface, and size range of about $17 \mathrm{~nm}$ Fig. (1A). The particle size distribution curve obtained from DLS measurements are presented in Fig. (1B) and (1C). The nanoparticle surface charge (or zeta potential) was $+52.5 \mathrm{mV}$. X-Ray powder diffraction pattern (XRD) of ChNPs is shown in Fig. (1D). No peak was found in the diffractograms. ChNPs were comprised of a dense network structure of interpenetrating polymer chains cross-linked to each other by TPP counter ions (Tang et al., 2003). The XRD implicated greater disarray in chain alignment in the nanoparticles after crosslinks. 

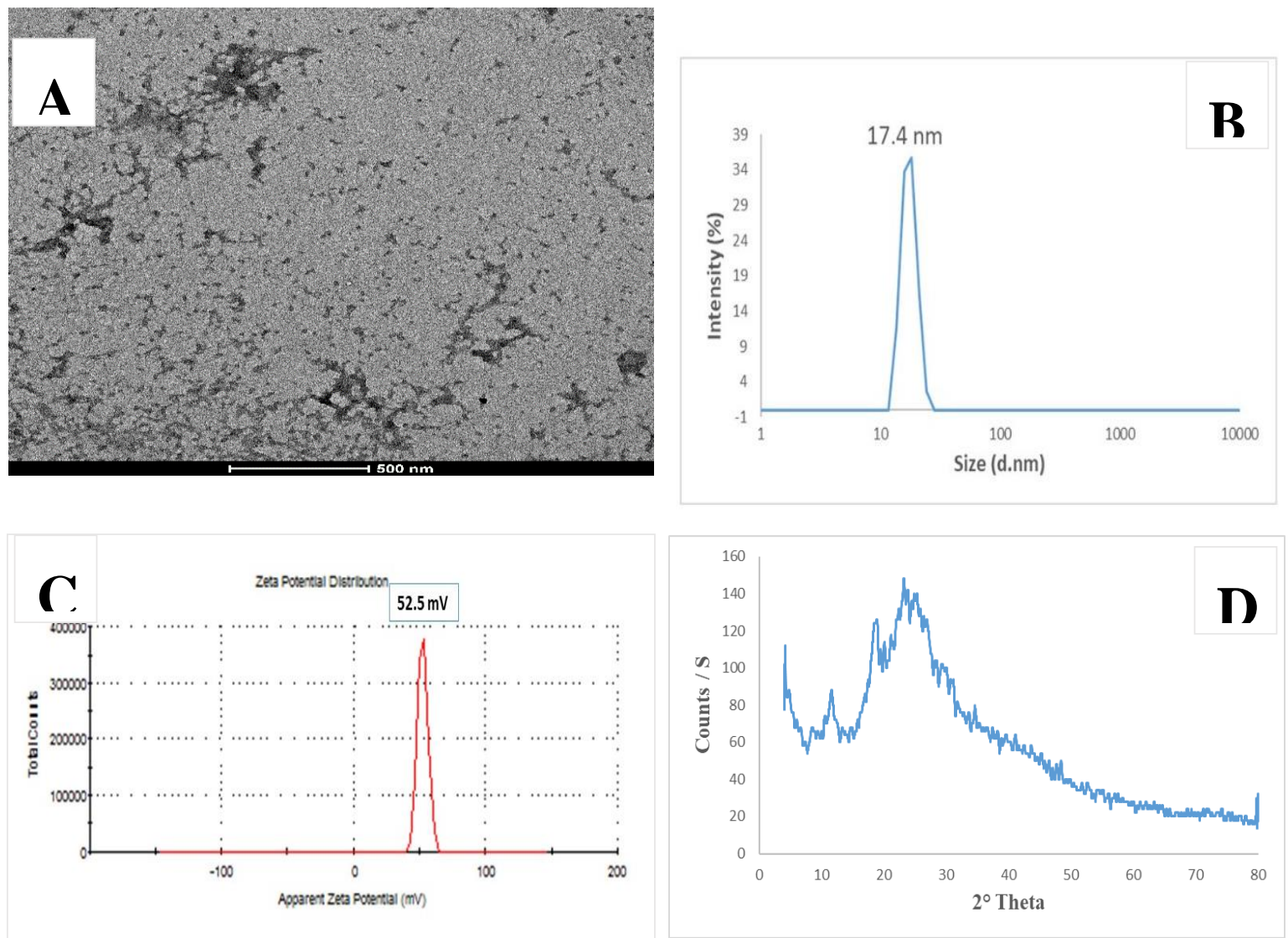

Fig (1). Characterization of chitosan nanoparticles (ChNPs).

(A): HRTEM image showing nearly spherical shape of prepared chitosan nanoparticles with average size $17 \mathrm{~nm}$.

(B): Particle size distribution of prepared chitosan nanoparticles showing the average size of $17 \mathrm{~nm}$.

(C): Zeta potential of prepared chitosan nanoparticles showing surface charge, zeta potential, $+52.5 \mathrm{mV}$.

(D): XRD pattern analysis indicating the formation of chitosan nanoparticles.

\section{Laying performance:}

The effects of chitosan supplementation on the egg production of laying hens are shown in Table (2). The laying egg rate, average egg weight and FCR of laying hens were not affected significantly by the experimental groups. These results are consistent with the results reported by Nogueira et al. (2003) who found that egg weight was not affected by supplementation of 20 or $30 \mathrm{~g}$ chitosan/ $\mathrm{kg}$ diet during 29-37 weeks of age. Egg production was not affected by supplementation of chito-oligosaccharides (COS) $(0.01 \%, 0.02 \%)$ in the diet Yan et al. (2010). The egg mass and feed intake were significantly decreased $(\mathrm{P}<0.05)$ in all treatments $(\mathrm{T} 1, \mathrm{~T} 2$ and $\mathrm{T} 3)$ compared to the control group, These results may be due to the high viscosity and the slow motility of chitosan in the gastrointestinal tract (Osho and Adeola, 2019). However, knowledge of the effects of ChNP on laying hens is still relatively limited. These results are agreement with the results reported by Xu et al. (2019) found that the addition of 200 or $400 \mathrm{mg} / \mathrm{kg}$ diet resulted in insignificant reduced feed intake compared to the control group of weaned pigs at 28 days; however, they reported that feed and weight gain were decreased $(\mathrm{P}<0.05)$ when the 


\section{Hamady and Farroh}

supplementation of ChNP increased to 200 or $400 \mathrm{mg} / \mathrm{kg}$ diet for 28 days in weaned pigs. The mortality ratio was not recorded for all treatments during the experimental period.

Table (2): Effect of adding $\mathrm{OCh}$ and $\mathrm{ChNP}$ on productive performance of laying hens from 23 to 34 weeks of age.

\begin{tabular}{|c|c|c|c|c|c|c|}
\hline \multirow{2}{*}{ Item } & \multicolumn{3}{|c|}{ Treatment } & & \multirow[t]{2}{*}{ SEM } & \multirow{2}{*}{$p$-value } \\
\hline & $\mathrm{Co}$ & $\mathrm{T} 1$ & $\mathrm{~T} 2$ & T3 & & \\
\hline Laying egg rate $(\%) /$ bird & 84.91 & 80.83 & 82.75 & 81.91 & 0.734 & 0.249 \\
\hline Average egg weight (g) & 60.69 & 58.26 & 60.12 & 59.13 & 0.386 & 0.119 \\
\hline Egg mass $(\mathrm{Kg}) / \mathrm{bird}$ & $4.325^{\mathrm{a}}$ & $3.955^{\mathrm{c}}$ & $4.125^{\mathrm{b}}$ & $4.066^{\mathrm{bc}}$ & 0.032 & 0.000 \\
\hline Feed intake $(\mathrm{Kg}) /$ bird & $9.701^{\mathrm{a}}$ & $8.634^{c}$ & $9.187^{b}$ & $8.972^{b c}$ & 0.089 & 0.000 \\
\hline Feed conversion ratio & 2.24 & 2.19 & 2.23 & 2.21 & 0.023 & 0.867 \\
\hline Mortality ratio & ND & ND & ND & ND & - & - \\
\hline
\end{tabular}

\section{Egg quality:}

Analysis of the data presented in Table (3) showed the effects of chitosan supplementation on egg quality. The addition of chitosan in the diet did not significantly $(\mathrm{P}<0.05)$ affect egg weight, yolk weight, shell weight, albumen weight, shell thickness and yolk color. While, the albumen height and Haugh Unit were significantly increased in the T1 and T3 groups compared to the control group. However, knowledge of the effects of ChNP on

Table (3): Effect of adding OCh and ChNP on egg quality of laying hens from 23 to 34 weeks of age.

\begin{tabular}{|c|c|c|c|c|c|c|}
\hline \multirow[t]{2}{*}{ Item } & \multicolumn{3}{|c|}{ Treatment } & & \multirow[t]{2}{*}{ SEM } & \multirow{2}{*}{$p$-value } \\
\hline & $\mathrm{Co}$ & $\mathrm{T} 1$ & $\mathrm{~T} 2$ & T3 & & \\
\hline Egg weight (g). & 59.13 & 57.91 & 58.35 & 57.78 & 0.217 & 0.113 \\
\hline Yolk weight (g). & 14.45 & 14.40 & 14.68 & 14.19 & 0.106 & 0.451 \\
\hline Shell weight (g). & 6.22 & 6.13 & 5.90 & 6.04 & 0.065 & 0.273 \\
\hline Albumen weight (g). & 38.44 & 37.37 & 37.76 & 37.53 & 0.157 & 0.077 \\
\hline Shell thickness (mm). & 0.394 & 0.389 & 0.392 & 0.393 & 0.002 & 0.800 \\
\hline Yolk color. & 7.87 & 8.04 & 7.95 & 8.00 & 0.090 & 0.929 \\
\hline Albumen height (mm). & $7.24^{c}$ & $7.41^{\mathrm{a}}$ & $7.26^{\mathrm{bc}}$ & $7.32^{\mathrm{b}}$ & 0.014 & 0.000 \\
\hline Haugh Unit. & $85.43^{c}$ & $86.78^{\mathrm{a}}$ & $85.77^{b c}$ & $86.30^{\mathrm{ab}}$ & 0.113 & 0.000 \\
\hline
\end{tabular}

OCh (chitosan ordinary) and ChNP (chitosan nanoparticles). Co (without supplementation), $T_{1} 200$ OCh mg/kg diet, $T_{2} 50$ $\mathrm{ChNP} / \mathrm{kg}$ diet and $T_{3} 200 \mathrm{ChNP} / \mathrm{kg}$ diet. SEM: standard error of the means. a,b and c mean the same raw having the different superscripts are significantly different $(p<0.05)$.

the dietary of laying hen appears limited and we have been unable to find any other study to confirm this result. Further study is needed to demonstrate the effect of ChNP addition in the laying hen. A similar finding was noted by Yoo et al. (2006) who found that the Haugh unit was improved with chitosan supplementation in the diet of 
laying hens. Furthermore, Nogueira et al. (2003) found that egg weight and egg component weights were not affected by supplementation of 20 or $30 \mathrm{~g}$ chitosan $/ \mathrm{kg}$ diet during 29-37 weeks of age. In other studies, supplementation of chito-oligosaccharides in the diet of laying hens had a positive effect on egg quality Yan et al. (2010) and Meng et al. (2010).

\section{Fatty acids, lipid oxidation and cholesterol content in egg yolk:}

Table (4) shows the effects of chitosan supplementation on fatty acids, cholesterol content and lipid oxidation in the yolk of laying hens. The data revealed that palmitic acid was not affected by treatments. The lowest content of stearic acid was in the egg yolk in the $\mathrm{T} 1$ group, which fed a diet containing $200 \mathrm{mg}$ OCh $(\mathrm{P}<0.05)$. In contrast, the highest content of hexadecenoic acid, oleic acid, octadecadienoic acid, arachidonic acid and eicosenoic acid was in the yolk of the T1 and T3 groups. 2 USFAs were significantly increased in the T1 and T3 group compared to the other groups. Conversely, $\Sigma$ SFA values were significantly decreased in the T1 and T3 groups compared to the other groups. Lipid oxidation was determined by malondialdehyde, which significantly decreased in the T1 and T3 groups. The cholesterol content of yolk was not affected significantly by treatments, although the T1 and T3 groups were decreased numerically compared to the other groups. These results may be due to that the chitosan have the ability to bind to dietary lipids and eliminate them in feces. This is consistent with

Table (4): Effect of adding OCh and ChNP on yolk fatty acid concentrations and cholesterol content of laying hens at 34 weeks of age.

\begin{tabular}{|c|c|c|c|c|c|c|c|}
\hline \multirow[t]{2}{*}{ Item } & \multirow{2}{*}{$\begin{array}{c}\text { Fatty } \\
\text { acid( }(\%)\end{array}$} & \multicolumn{4}{|c|}{ Treatment } & \multirow[t]{2}{*}{ SEM } & \multirow{2}{*}{$p$-value } \\
\hline & & Co & $\mathrm{T} 1$ & $\mathrm{~T} 2$ & $\mathrm{~T} 3$ & & \\
\hline Palmitic acid & C16:0 & 27.29 & 24.99 & 26.86 & 25.09 & 0.417 & 0.100 \\
\hline Stearic acid & C18:0 & $16.11^{\mathrm{a}}$ & $12.64^{\mathrm{b}}$ & $15.15^{\mathrm{a}}$ & $14.49^{\mathrm{a}}$ & 0.382 & 0.004 \\
\hline Hexadecenoic acid & C16:1 & $2.22^{\mathrm{b}}$ & $2.81^{\mathrm{a}}$ & $2.06^{\mathrm{b}}$ & $2.72^{\mathrm{a}}$ & 0.087 & 0.000 \\
\hline Oleic acid & C18:1 & $39.12^{b}$ & $42.60^{\mathrm{a}}$ & $38.41^{\mathrm{b}}$ & $41.02^{\mathrm{ab}}$ & 0.531 & 0.012 \\
\hline Octadecadienoic acid & C18:2 & $8.31^{\mathrm{b}}$ & $10.42^{\mathrm{a}}$ & $10.11^{\mathrm{a}}$ & $10.43^{\mathrm{a}}$ & 0.310 & 0.033 \\
\hline Arachidonic acid & $\mathrm{C} 20: 4$ & $0.76^{\mathrm{c}}$ & $1.07^{\mathrm{ab}}$ & $0.96^{\mathrm{bc}}$ & $1.22^{\mathrm{a}}$ & 0.049 & 0.002 \\
\hline Eicosenoic acid & $\mathrm{C} 20: 1 \mathrm{n} 9$ & $0.56^{\mathrm{c}}$ & $1.43^{\mathrm{a}}$ & $0.84^{\mathrm{b}}$ & $1.26^{\mathrm{a}}$ & 0.077 & 0.000 \\
\hline$\Sigma$ USFA & & $51.44^{\mathrm{b}}$ & $58.24^{\mathrm{a}}$ & $52.50^{\mathrm{b}}$ & $56.20^{\mathrm{a}}$ & 0.698 & 0.000 \\
\hline$\Sigma \mathrm{SFA}$ & & $43.40^{\mathrm{a}}$ & $37.63^{\mathrm{c}}$ & $42.02^{\mathrm{ab}}$ & $39.58^{\mathrm{bc}}$ & 0.680 & 0.005 \\
\hline Malondialdehyde $\mathrm{nmol} / \mathrm{mL}$ & & $5.03^{\mathrm{a}}$ & $4.38^{\mathrm{b}}$ & $4.97^{\mathrm{a}}$ & $4.61^{\mathrm{b}}$ & 0.07 & 0.003 \\
\hline $\begin{array}{l}\text { Cholesterol content }(\mathrm{mg} / 100 \mathrm{~g} \\
\text { yolk) }\end{array}$ & & 1023 & 968 & 1016 & 1001 & 15.14 & 0.611 \\
\hline
\end{tabular}

¿USFA Unsaturated fatty acids. SSFA Saturated fatty acids. OCh (chitosan ordinary) and ChNP (chitosan nanoparticles). Co (without supplementation), $T_{1} 200 \mathrm{OCh} \mathrm{mg} / \mathrm{kg}$ diet, $T_{2} 50 \mathrm{ChNP} / \mathrm{kg}$ diet and $T_{3} 200 \mathrm{ChNP} / \mathrm{kg}$ diet. SEM: standard error of the means. $a, b$ and $c$ mean the same raw having the different superscripts are significantly different $(P<0.05)$.

previous studies on hypolipidemic effects of chitosan (Zhang et al. 2012 and 2013). These results are consistent with the results reported by Nogueira et al. (2003) who found that palmitic and stearic acid contents in eggs were lower in the groups given $20 \mathrm{~g}$ or $30 \mathrm{~g}$ than the group given a basal diet, while oleic acid in eggs in the group 


\section{Hamady and Farroh}

given $30 \mathrm{~g}$ was higher than the group fed on a basal diet at 37 weeks of age. The egg yolk cholesterol levels were reduced by a diet containing $30 \mathrm{~g} / \mathrm{kg}$ chitosan at 35 - 37 weeks of age compared to the control group, which fed a basal diet. Also, Abdel-Wahhab et al. (2017) reported that serum malondialdehyde was decreased significantly by the high dose of ChNP (280 mg / $\mathrm{kg}$ body weight) in rats. Contrary to our results, Li et al, (2015) found that the medium and high molecular weight of chitosan increased the serum malondialdehyde.

\section{Blood serum measurements:}

Results of blood serum tests are shown in Table (5). There were no differences $(\mathrm{P}<0.05)$ in the total serum protein, total cholesterol, high density lipoproteins, low density lipoproteins, immunoglobulin A and immunoglobulin $\mathrm{M}$ among all treatments. immunoglobulin $\mathrm{Y}$ was significantly increased $(\mathrm{P}<0.05)$ for group fed T1 followed by decreasing order by T3. These results may be due to the presence of the amine group in the synthesis of chitosan, which stimulates the immune system to produce antibodies and thus improves the immune response (Li et al., 2016 and Tokura et al., 1999). These results are in agreement with the results reported by Miao et al. (2020). Conversely, Xu et al. (2019) reported that supplementation of 200 or $400 \mathrm{mg} \mathrm{ChNP/kg}$ diet leads to an increased plasma immunoglobulin concentration ( $\mathrm{IgG})$ in weaned pigs at 28 days, whereas $\operatorname{IgM}$ concentration was not affected by ChNP. Pigs fed with a basic diet containing 50 or $100 \mathrm{mg} / \mathrm{kg}$ of low molecular weight chitosan showed an increased levels of serum IgG and IgM compared to the control group, whereas IgA concentration was not affected Zhanga et al. (2020). No differences were found among experimental groups $(\mathrm{P}>0.05)$ in serum immunoglobulins (IgA and IgM). These results may be due to non-repeated injection of sheep red blood cells (SRBC) before blood samples were-drawn.

Table (5): Effect of adding OCh and ChNP on blood serum parameters of of laying hens at 34 weeks of age.

\begin{tabular}{|c|c|c|c|c|c|c|}
\hline \multirow{2}{*}{ Item } & \multicolumn{4}{|c|}{ Treatment } & \multirow{2}{*}{ SEM } & \multirow{2}{*}{$p$-value } \\
\hline & $\mathrm{Co}$ & T1 & $\mathrm{T} 2$ & T3 & & \\
\hline Total protein $(\mathrm{mg} / \mathrm{dL})$ & 6.27 & 6.10 & 6.15 & 5.97 & 0.136 & 0.911 \\
\hline Total cholesterol (mg/dL) & 151.25 & 141.00 & 144.66 & 139.50 & 2.55 & 0.387 \\
\hline High density lipoproteins (mg/dL) & 63.35 & 69.25 & 66.02 & 71.02 & 1.95 & 0.098 \\
\hline Low density lipoproteins (mg/dL) & 56.50 & 50.31 & 53.89 & 49.91 & 1.50 & 0.373 \\
\hline Immunoglobulin $\mathrm{A}(\mu \mathrm{g} / \mathrm{mL})$ & 78.73 & 83.06 & 79.66 & 82.00 & 0.921 & 0.327 \\
\hline Immunoglobulin $\mathrm{Y}(\mu \mathrm{g} / \mathrm{mL})$ & $378.83^{\mathrm{b}}$ & $428.00^{\mathrm{a}}$ & $383.33^{b}$ & $404.66^{\mathrm{ab}}$ & 6.71 & 0.025 \\
\hline Immunoglobulin $\mathrm{M}(\mu \mathrm{g} / \mathrm{mL})$ & 156.83 & 166.33 & 158.50 & 162.83 & 3.44 & 0.785 \\
\hline
\end{tabular}

OCh (chitosan ordinary) and ChNP (chitosan nanoparticles). Co (without supplementation), $T_{1} 200 \mathrm{OCh} \mathrm{mg} / \mathrm{kg} \mathrm{diet,} T_{2} 50$ ChNP $/ \mathrm{kg}$ diet and $T_{3} 200 \mathrm{ChNP} / \mathrm{kg}$ diet. SEM: standard error of the means. a,b, $c$ and $d$ mean the same raw having the different superscripts are significantly different $(P<0.05)$.

\section{Microbial population:}

Table (6) reveals that total bacterial count, and Lactobacillus count of intestine were significantly increased $(\mathrm{P}<0.05)$ in the Och and the high dose of ChNP fed groups (T1 and T3) compared to the control group. Conversely, the Escherichia coli count was significantly decreased in the T1 and T3 groups. Both of Salmonella and Clostridia were not found for all groups.In the current study, the intestinal bacterial composition showed 
differences among groups. Whereas, laying hens that fed $200 \mathrm{mg}$ OCh or $200 \mathrm{mg} / \mathrm{kg}$ diet ChNP enhanced total bacterial count and Lactobacillus count in the intestine. Conversely, the Escherichia coli was significantly decreased by the same groups. Both 2 ordinary chitosan $(200 \mathrm{mg}$ ) and ChNPs (200 $\mathrm{mg}$ ) have a positive effect on the intestinal bacterial community of laying hens. To our knowledge, this is the first study to evaluate the effects of ChNP supplementation with size up to $17 \mathrm{~nm}$ in laying hens. These results are consistent with the results reported by Xu et al. (2019) who showed that ChNPs might increase the presence of the useful bacterial species and reduce the pathogenic bacterial species. Conversely, Abd El-Naby et al. (2019) found that ChNP supplementation in the diet of Oreochromis niloticus leads to the inhibition of the growth of intestinal bacterial assemblies. However, to evaluate the diversity changes at a larger scale (i.e. minor bacterial populations), next-generation sequencing combined with specific PCR assays are essential.

Table (6): Effect of adding OCh and ChNP on bacterial count in the intestinal contents of laying hens at 34 weeks of age.

\begin{tabular}{|c|c|c|c|c|c|c|}
\hline \multirow[b]{2}{*}{ Item } & \multicolumn{3}{|c|}{ Treatment } & \multirow{2}{*}{\multicolumn{2}{|c|}{ SEM }} & \multirow{2}{*}{$p$-value } \\
\hline & $\mathrm{Co}$ & $\mathrm{T} 1$ & $\mathrm{~T} 2$ & & & \\
\hline Total bacteria count $\left(\times 10^{7}\right)^{2}$ & $6.42 \mathrm{~b}$ & $8.21^{\text {a }}$ & $7.27 \mathrm{ab}$ & $8.68^{\text {a }}$ & 0.29 & 0.024 \\
\hline Lactobacillus count $\left(\times 10^{4}\right)^{2}$ & $4.43^{c}$ & $5.52^{a b}$ & $4.81 \mathrm{bc}$ & 5.83 a & 0.16 & 0.003 \\
\hline Escherichia coli $\left(\times 10^{4}\right)^{2}$ & $8.07^{\text {a }}$ & $6.12 \mathrm{~b}$ & $6.95^{\mathrm{ab}}$ & $5.62 \mathrm{~b}$ & 0.33 & 0.045 \\
\hline Salmonella & ND & ND & ND & ND & ND & ND \\
\hline Clostridia & ND & ND & ND & ND & ND & ND \\
\hline
\end{tabular}

Co (without supplementation), $T_{1} 200 \mathrm{OCh} \mathrm{mg} / \mathrm{kg}$ diet, $T_{2} 50 \mathrm{ChNP} / \mathrm{kg}$ diet and $T_{3} 200 \mathrm{ChNP} / \mathrm{kg}$ diet. SEM: standard error of the means. $a, b$ and $c$ mean the same raw having the different superscripts are significantly different $(P<0.05)$. ND. Not detected.

\section{CONCLUSION}

It could be concluded that addition of chitosan at $200 \mathrm{mg} / \mathrm{kg}$ diet of laying hens in both forms (chitosan nanoparticles "with a size of up to $17 \mathrm{~nm}$ " or ordinary chitosan) improved some production traits, such as egg quality, egg yolk composition, immunity and intestinal bacteria. Therefore, chitosan nanoparticles (ChNP) could be used as a potential supplement in the diets of laying hens. Future studies for investigation of the host pathogen interaction in the context of the feed additive containing chitosan and chitosan nanoparticles would be useful in corroborating our findings.

\section{REFERENCES}

Abd El-Naby, F.S., M.A.E. Naiel, A.A.Al-Sagheer and S.S. Negm (2019). Dietary chitosan nanoparticles enhance the growth, production performance, and immunity in Oreochromis niloticus. Aqua. 501: 82-89. https://doi.org/ 10.1016/ j.aquaculture. 2018. 11.014.

Abdel-Wahhab, M.A., A. Aljawish, A. A. El-Nekeety, S. H. Abdel-Aiezm and N. S. Hassan (2017). Chitosan nanoparticles plus quercetin suppress the oxidative stress, modulate DNA fragmentation and gene expression 


\section{Hamady and Farroh}

in the kidney of rats fed ochratoxin A-contaminated diet. Food Chem. Toxicol. 99: 209-221. doi: 10.1016/j.fct.2016.12.002.

AOAC (2012). Official methods of analysis. Association of Official Analytical Chemists. Washington, D.C.

Attia, Y.A., A. A. Bakhashwain and N. K. Bertu (2018). Utilisation of thyme powder (Thyme vulgaris L.) as a growth promoter alternative to antibiotics for broiler chickens raised in a hot climate. Europ. Poult. Sci. 82: 15. [Google Scholar] [CrossRef].

Calvo, P., C.Remu Nán-López and M. J. Vila-Jato Alonso (1997). Novel hydrophilic chitosan-polyethylene oxide nanoparticles as protein carrier. J. Appl. Polym. Sci. 63: 125-132.

Duncan, D. B. (1955). Multiple range and multiple F-test.Biometrics. 11: 1-42. http://dx.doi.org/10.2307/3001478.

European Union. (2003). Regulation (EC) No. 1831/2003 of the European Parliament and the council of 22 September 2003 on additives for use in animal nutrition. Off. J. Eur. Union. Oct 18; L 268: p. 29. lastly amended by regulation (EC) No. 767/2009. [Google Scholar].

Folch, J., M. Lees and G. H. Sloane-Stanely (1957). A simple method for the isolation and purification of total lipids from animal tissues. J. Biol. Chem. 226:497-507.

Haugh, R.R. (1937). The Haugh unit for measuring egg quality. U.S. Egg Poul. Mag. 43:522-555.

Henry, R. J., D. C. Canmon and J. W. Winkelman (1974). Principles and techniques, Harper and Row. Clin. Chem. 415.

Hirano, S., C. Itakura, H. Seino, Y. Akiyama, I. Nonaka, N. Kanbara and T. Kawakami (1990). Chitosan as an ingredient for domestic animal feeds. J. Agric. Food Chem. 38: 1214-1217.

Hogenesch, H., A. D. Dunham, C. Scott-Moncrieff, L. T. Glickman and D. J. Deboer (2002). "Effect of Vaccination on Serum Concentrations of Total and Antigen-Specific Immunoglobulin E in Dogs." Amer. J. Vet. Res.63: 611-616. https://doi.org/10.2460/ajvr.2002.63.611.

Kong, M. X., G. Chen, K. Xing and H. J. Park (2010). Antimicrobial properties of chitosan and mode of action: A state of the art review. Int. J. Food Microbiol. 144:51-63. [Google Scholar] [CrossRef] [PubMed] https://doi.org/10.1016/j.ijfoodmicro.2010.09.012.

Li, Q.P., S. R. Gooneratne, R. L. Wang, R. Zhang, L. L. An, J. J. Chen and W. Pan (2015). Effect of different molecular weight of chitosans on performance and lipid metabolism in chicken. Anim. Feed Sci. Tech. 211:174-180. http://dx.doi.org/10.1016/j.anifeedsci. 2015.11.013.

Li, T., R. Na, P. Yu, B. Shi, S. Yan, Y. Zhao and Y. Xu (2016). Effects of dietary supplementation of chitosan on immune and antioxidative function in beef cattle. Czech J. Anim. Sci. 60:38- 44. doi: 10.17221/43/2014-CJAS.

Lopez - Virella M.F., P. Stone, S. Ellis and J. A. Colwell (1977). Cholesterol determination in high density lipoproteins separated by three different methods. Clin. Chem. 23: 882.

Mannheim, B. (1989). Methods of Biochemical Analysis and Food Analysis. Boehringer Mannheim GmbH 
Biocemica, Mannheim, Germany. 26-28.

Meng, Q. W., L. Yan, X. Ao, H. D. Jang, J. H. Cho and I. H. Kim (2010). Effects of chito-oligosaccharide supplementation on egg production, nutrient digestibility, egg quality and blood profiles in laying hens. Asian Austral. J. Anim. Sci. 23:1476-1481.

Miao, Z., W. Zhao, L. Guo, S. Wang and I. Zhang (2020). Effects of dietary supplementation of chitosan on immune function in growing Houyan geese. Poult. Sci.99:95-100 http://dx.doi.org/10.3382/ps/pez565.

Naskar, S., S. Sharma and K. Kuotsu (2019). Chitosan-based nanoparticles: An overview of biomedical applications and its preparation. J. Drug Deliv. Sci. Tech. 49: 66-81. [Google Scholar] [CrossRef]. https://doi.org/10.1016/j.jddst.2018.10.022.

NRC, (1994). National Research Council. Nutrient requirements of poultry, 9th rev. Ed. National Academy Press, Washington, D.C.

Nogueira, C. M., J. F. F. Zapata, M. F. F. Fuentes, E. R. Freitas, A. A. Craveiro and C. M. Aguiar (2003). The effect of supplementing layer diets with shark cartilage or chitosan on egg components and yolk lipids. Br. Poult. Sci. 44: 218-223.

Nwe, N., T. Furuike and H. Tamura (2009). The mechanical and biological properties of chitosan scaffolds for tissue regeneration templates are significantly enhanced by chitosan from gongronella butleri. Mater. 2:374-398. https://doi.org/10.3390/ma2020374.

Osho, S. O. and O. Adeola (2019). Impact of dietary chitosan oligosaccharide and its effects on coccidia challenge in broiler chickens. Br. Poult. Sci. 766-776. https://doi.org/10.1080/00071668.2019.1662887.

Pearson's Chemical Analysis of Food Eighth Edition (1981). Edinburgh, New York, Churchill Livingstone.

Quinn, P. J., M. E. Carter, B. K. Markey and G. R. Carter (1994). Clinical veterinary microbiology, Wolf, London. ISBN 0-7234-1711-3.

Racanicci, A. M. C., J.F.M. Menten, M.A.B. Regitano-d'Arce, F.S. Torres, L.M. Pino and A. A. Pedroso (2008). Dietary oxidized poultry offal fat: broiler performance and oxidative stability of thigh meat during chilled storage 1. Braz. J. Poult. Sci. 10:29-35. https://doi.org/10.1590/S1516-635X2008000100005.

Rada, V., K. Sirotek and J. Petr (1999). Evaluation of selective media for bifidobacteria in poultry and rabbit caecal samples. J. Vet. Med. B. 46: 369-373.https://doi.org/10.1046/j.1439-0450.1999.00241.x

Richmond, W. (1973). Preparation and properties of a cholesterol oxidase from nocardia sp. and its application to the enzymatic assay of total cholesterol in serum. Clin. Chem. 19: 1350-1356. https://doi.org/10.1093/clinchem/19.12.1350.

Singla, A. K. and M. Chawla (2001). Chitosan: some pharmaceutical and biological aspects: an update. J. Pharm. Pharmacol. 53: 1047-1067. https://doi.org/10.1211/0022357011776441.

Sirsat Shraddha, D., P. Visha and K. Nanjappan (2017). Effects of Dietary Chitosan and Neem Leaf Meal Supplementation on Digestive Enzyme Activities and Fat Deposition in Broiler Chickens. Int. J. Curr. Microbiol. App. Sci. 6: 469-475. 


\section{Hamady and Farroh}

SPSS (2001). for windows S, Chicago, IL SPSS Computer software 11.00. SPSS Inc., Headqurters. Wacker Drive,Chicago, Illinois 60606, USA. Pp. 233.

Swiatkiewicz, S., M. Swiatkiewicz, A. Arczewska-Wlosek and D. Jozefiak (2015). Chitosan and its oligosaccharide derivatives (chito-oligosaccharides) as feed supplements in poultry and swine nutrition. J. Anim. Physiol. An. N. 99: 1-12.

Tang, E. S. K., M. Huang and L. Y. Lim (2003). Ultrasonication of chitosan and chitosan nanoparticles. Int. J. Pharm. 265: 103-114. https://doi.org/10.1016/S0378-5173(03)00408-3.

Tetra-SL LL guide, (2018). Commercial Layer Management Guide. www.babolnatetra.com.

Tokura, S., H.Tamura and I. Azuma (1999). Immunological Aspects of Chitin and Chitin Derivatives Administered to Animals. EXC. 87: 279-292. [Google Scholar]DOI: 10.1007/978-3-0348-8757-1_20 PMID: 10906967.

Tømmeraas, K., S. P. Strand, B. E. Christensen, O. Smidsrød and K. M. Vårum (2011). Preparation and characterization of branched chitosans.Carbohydr. Polym. 83: 1558-1564. https://doi.org/10.1016/j.carbpol.2010.10.008.

Wang, W., Q. Meng, Q. Li, J. Liu, M. Zhou, Z. Jin and K. Zhao (2020). Chitosan derivatives and their application in biomedicine. Int. J. Mol. Sci. 21: 487. [Google Scholar] [CrossRef]. https://doi.org/10.3390/ijms21020487.

Wieland H. and D. Seidel (1983). A simple specific method for precipitation of low density lipoproteins.

J. lipid Res. 24: 904-909.

Xu, Y., H. Mao, C. Yang, H. Du, H. Wang and J. Tu (2019). Effects of chitosan nanoparticle supplementation on growth performance, humoral immunity, gut microbiota and immune responses alter lipopolysaccharide challenger in weaned pigs. J. Anim. Physiol. An. N. 104: 597-605. [Google Scholar] [CrossRef] https://doi.org/10.1111/jpn.13283.

Yan, L., J. H. Lee, Q. W. Meng, X. Ao and I, H, Kim (2010). Evaluation of dietary supplementation of delta-aminolevulinic acid and chitooligosaccharide on production performance, egg quality and hematological characteristics in laying hens. Asian Austral. J. Anim. Sci. 23: 1028-1033.

Yin, H., Y. Du and J. Zhang (2009). Low molecular weight and oligomeric chitosans and their bioactivities. Curr. Top. Med. Chem.9: 1546-1559.

Yoo, J.S., J. D. Kim, J. H. Cho, Y. J. Chen, H. J. Kim, B. J. Min, D. K. Kabg and I.H. Kim (2006). Effect of natural mineral complex and chitosan supplementation on egg production and characteristics in laying hens. Korean J. Poult. Sci. Vol.33, Iss.4, 309-316.

Zhang, J., W. Zhang, B. Mamadouba and W. A. Xia (2012). comparative study on hypolipidemic activities of high and low molecular weight chitosan in rats. Int. J. Biol. Macromol. 51: 504-508. https://doi.org/10.1016/j.ijbiomac.2012.06.018.

Zhang, W., J. Zhang, Q. Jiang and W. Xia (2013). The hypolipidemic activity of chitosan nanopowder prepared by ultrafine milling. Carbohydr. Polym. 95: 487-491. https://doi.org/10.1016/j.carbpol.2013.02.037. 
Zhanga, J., G. Wub, D. Chena, B. Yua, Z. Huanga, X. Maoa, P. Zhenga, J. Yua and J. Heam (2020). Low-molecular-weight chitosan relieves enterotoxigenic Escherichia coli- induced growth retardation in weaned pigs. Int. Immunopharmacology. 78: 1057982. https://doi.org/10.1016/j.intimp.2019.105798.

Zhou, T. X., J. H. Cho and I. H Kim (2012). Effects of supplementation of chito-oligosaccharide on the growth performance, nutrient digestibility, blood characteristics and appearance of diarrhea in weanling pigs. Livest. Sci. 144: 263-268. [CrossRef] https://doi.org/10.1016/j.livsci.2011.12.009.

\section{تأثيرات إضافة النانو شيتوزان على الأداء الانتاجى للاجاج البياض}

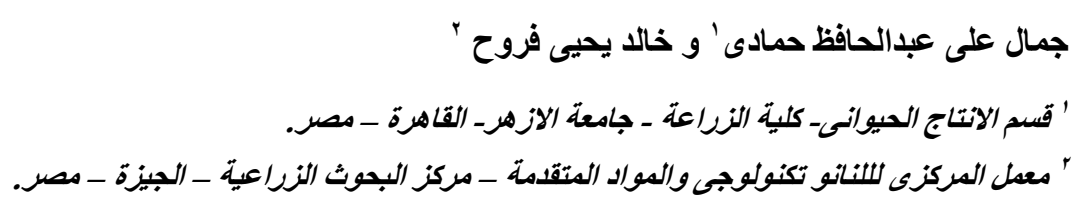

أجريت هذه الدر اسة في محطةِ بحوث الدواجنَ، كليّة الزر اعة ، جامعة الأزهر ، القاهرة ، جمهورية مصر العربية. وكان الهدف من هذة الدر اسة

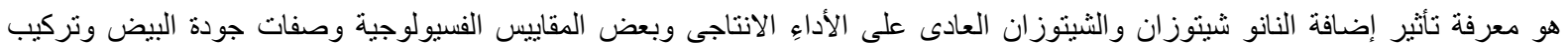

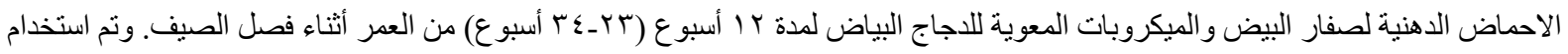
ج 9 دجاجة بياضة من سلالة (TETRA-SL) عمر يوم ، وتم توزيعهم عشو ائيًا إلى ؛ معاملات كل معاملة تحتوى على ب مكرارات وكل مكررة تحتوى على ع عيون وكل عين r دجاجة. وكانت المعاملات كالتالى:المجموعة الأولى: مجموعة المقارنة في الظروف المتلى (تغذية حرة حتى الثبع).

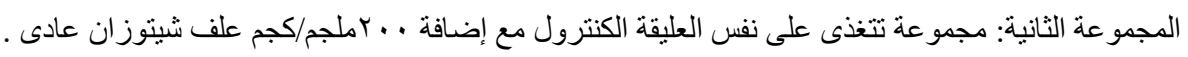

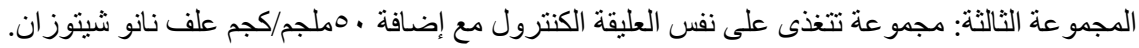

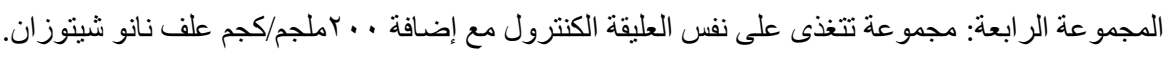
و كانت النَتائج المكتسبة لُخّصت كالاتى: الصفات الانتاجية:-

لم يكن هناك فروق معنوية لكلا من معدل انتاج البيض ومتوسطوزن البيض ومعدل التحويل الغذائي بين المعاملات. بينما سجلت المعاملة المقارنة

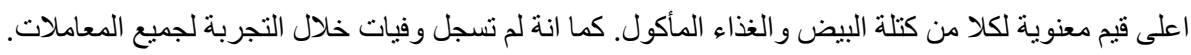

$$
\text { صفات جودة البيض: }
$$

سجلت المعاملة الثانية والرابعة اعلى قيم معنوية لكلا من ارتفاع الالبيومين و وحدة هيو مقارنة بباقى المعاملات. ولم يلاحظ فروق معنوية بين المعاملات في باقى الصفات (وزن البيض- وزن الصفار - وزن الالبيومين - وزن قشرة البيضة ـ سمك القشرة - لون الصفار )

$$
\text { تركيب الصفار: }
$$

سجلت المعاملة الثانية و الر ابعة اعلى قيم معنوية لكلا من الاحماض الدهنية غير المشبعة لصفار البيض و اقل قيم معنوية للاحماض الدهنية المشبعة مقارنة بباقى المعاملات. كما سجلت نفس المعاملتين اقل قيم معنوية لكلا من محتوى الكوليستيرول و malondialdehyde مقارنة بياقى المعاملات.

$$
\text { مكونات سيرم الدم: }
$$




\section{Hamady and Farroh}

جميع مقاييس الدم كانت داخل المعدل الطبيعى ، كما انة لم بلاحظ اى فروق معنوية بين المعاملات في الصفات المقاسة (البروتين الكلى ـالكوليستيرول الكلى و الكوليستيرول منذفض الكثافة و العالى الكثافةـ الاجسام المناعية Igm -Igg بينما سجلت المعاملات الثانية و الربعة اعلى قيمة معنوية للاجسام المناعية IgY الكركئرو

الميكروبات المعوية :أثارت النتائج الى أن العد الكلى للبكتريا فى الأمعاء واللاكتوباسلس كان أعلى معنويا في المعاملات التى تم إضافة الثيتوزان

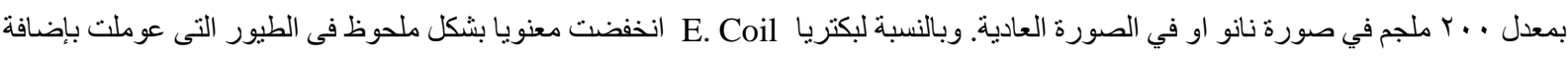

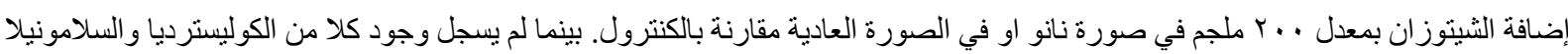
لجميع المعاملات.

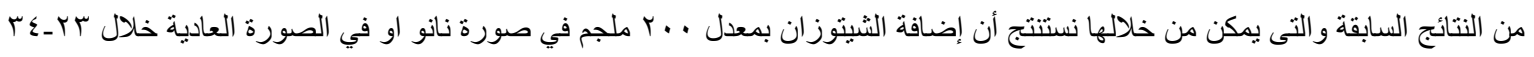
أسبوع من عمر الدجاج البياض يعمل على تحسين مكونات صفار البيض ويرفع المناعة ويحسن بيئة الأمعاء الميكروبية بدون تأثير سلبى على الانتاج ووظائف الجسم. 